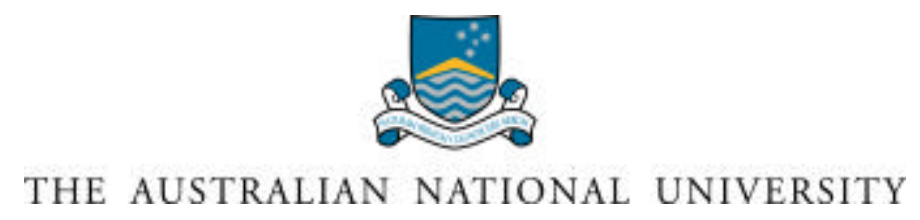

Working Paper Series in Finance 00-04

\title{
SELECTING MACROECONOMIC VARIABLES AS EXPLANATORY FACTORS OF EMERGING STOCK MARKET RETURNS
}

\author{
C.M. Bilson \\ T.J. Brailsford \\ V.J. Hooper \\ Department of Commerce \\ Australian National University
}

JEL Classification

Keywords

Last revision date:

Contact author:

\author{
F30, G12, G15 \\ Emerging Stock Markets; Multi-factor Models; \\ International Asset Pricing; Macroeconomic \\ Forces \\ April 2000 \\ Chris Bilson \\ Department of Commerce \\ The Australian National University \\ Canberra ACT 0200 AUSTRALIA \\ Telephone: 0262494861 (International +61 26249 4861) \\ Facsimile: 0262495005 (International +61 26249 5005) \\ Email: Chris.Bilson@anu.edu.au
}

The working paper series is for manuscripts in draft form. Comments are welcome and should be sent to the contact author. Please do not quote without permission.

(c) Copyright 2000 C.M. Bilson, T.J. Brailsford and V.J. Hooper 


\title{
SELECTING MACROECONOMIC VARIABLES AS EXPLANATORY FACTORS OF EMERGING STOCK MARKET RETURNS
}

\author{
Chris Bilson \\ Tim Brailsford \\ Vince Hooper \\ Department of Commerce \\ Australian National University \\ Canberra 0200 \\ AUSTRALIA
}

\begin{abstract}
Emerging stock markets have been identified as being at least partially segmented from global capital markets. As a consequence, it has been argued that local risk factors rather than world risk factors are the primary source of equity return variation in these markets. This paper seeks to address the question of whether macroeconomic variables may proxy for local risk sources. We find moderate evidence to support this hypothesis. Further, we investigate the degree of commonality in exposures across emerging stock market returns using a principal components approach. We find little evidence of commonality when emerging markets are considered collectively, however at the regional level considerable commonality is found to exist.
\end{abstract}

Acknowledgments: We thank Trevor Breusch, Robert Faff, Barry Oliver, and delegates at the Australasian Finance \& Banking Conference 1999 for their constructive comments on earlier drafts of the paper. 


\section{Introduction}

A number of studies document that a relationship exists between macroeconomic variables and equity market returns. Further, the APT literature suggests that macroeconomic variables may proxy for pervasive risk factors [Brown and Otsuki (1991); Priestley (1996); Kryzanowski et al (1997)]. This paper extends this literature by considering the relationship in an emerging markets context. To date, the literature on asset pricing in emerging markets has focused primarily on either microeconomic effects such as dividend yields and price-to-earnings ratios or the impact of world influences such as the world equity portfolio. Generally, the literature has ignored the potential impact that macroeconomic variables may have on emerging stock market returns.

There is evidence to suggest that emerging stock markets (ESMs) are segmented from world capital markets, and as a result local information has increased importance in the se markets [Harvey (1995b)]. A consequence of the segmented nature of these markets is that ESM returns are only weakly correlated with the returns from developed stock markets (DSMs). This allows an international investor to enhance the mean-variance efficiency of their portfolio [Errunza (1977); Divecha, Drach and Stefek (1992)]. The diversification benefits, however, will be greatest when the factors driving return variation are uncorrelated across markets.

Interest in ESMs has grown over the past decade. Given political and economic structures that previously existed, little was known about these markets and international investment levels were low, in part due to high cost barriers to entry. However, since the 1980s, there have been substantial changes in political and economic environments in many regions such as China, Eastern Europe, Latin America and Russia. As a result, emerging markets now represent a feasible investment alternative for international investors and the last decade has witnessed massive capital flows in and out of emerging stock markets. To illustrate, in 1994, the International Finance Corporation (IFC, 1995) recorded that the aggregate market value of emerging stock markets totalled USD $\$ 1,930$ billion, up nearly $21 \%$ from 1993 . New capital raised in 1994 for these markets was USD\$51.4 billion.

ESMs appear to have features that distinguish them from other stock markets. Returns and risks in ESMs have been found to be higher relative to developed markets ${ }^{1}$ [Errunza (1983); Wilcox (1992); Claessens, Dagupta and Glen (1993); and Harvey (1995a)]. Further, the returns

\footnotetext{
${ }^{1}$ However it is questionable as to whether these high and somewhat predictable returns are transitory in nature as evidenced by the substantial declines in market capitalisation in emerging markets that occurred during 1997 and 1998. In 1997 the International Finance Corporation Investable (IFCI) index fell 16\%, the sharpest one-year decline in the index's 10-year history. The IFCI Asia Index fell by 57\% [Emerging Stock Markets Factbook 1997].
} 
achievable from emerging stock markets appear more predictable than developed markets and exhibit stronger mean reversion properties [Harvey (1993), (1995a); Bekaert (1995); Bekaert and Harvey (1995)], with a higher degree of autocorrelation. ESMs appear to have varying degrees of segmentation. Bekaert and Harvey (1995) suggest that some emerging markets exhibit timevarying integration as they appear to be more integrated than expected based on prior knowledge of investment restrictions. Other markets appear to be quite segmented even though foreigners have relatively free access to their capital markets. Recent evidence by Goetzmann and Jorion (1999) shows that emerging markets may go through several phases of 'emergence' and should not be viewed as static.

In this paper, we examine the extent to which macroeconomic variables are able to explain the variation in equity returns in emerging stock markets. However, the ability of each macroeconomic variable to explain return variation in each market is expected to vary greatly. This is due to large differences in the return structure between markets, especially considering the wide range of market development of the ESMs in our sample. We therefore also investigate the degree of commonality between emerging market returns. To accomplish this we first extract the common variation in a combined variable set using Principal Components Analysis (PCA). The common variation, represented by the first four principal components, proxies for the 'true' source of return variation in each ESM. The results show that while ESMs are segmented to a degree, there is significant commonality in the return generating process across markets. As such, the findings have implications for international investors and the understanding of asset pricing as they imply that diversification benefits may be more efficiently achieved through concentrating on factor exposures rather than the markets themselves.

The paper is organised as follows. The next section presents a discussion of asset pricing and the role of macroeconomic factors in the context of ESMs. Section three presents the models while section four discusses the data used in the empirical tests. Section five analyses the results and the last section concludes the paper.

\section{Asset Pricing and Emerging Stock Markets}

The International Capital Asset Pricing Model (ICAPM), as developed by Solnik (1974), assumes a single factor return generating process. This model proposes that if markets are globally integrated, then asset returns will be determined by their exposure to a single priced world factor. Typically this risk source is assumed to be the return on a value-weighted world portfolio, such as the MSCI world index. However, problems are encountered in the application of the ICAPM to emerging markets. 
First, the world portfolio must be mean-variance efficient for it to be an appropriate benchmark to measure an asset's risk. Small degrees of inefficiency in the portfolio could result in no relation between the actual level of risk exposure and the expected return for a security [Roll and Ross (1994); Kandel and Stambaugh (1994)]. Harvey (1995) finds evidence that questions the meanvariance efficiency of the MSCI world index in an emerging stock market context.

Second, an additional difficulty arises from the assumption of integration. It is unlikely that any market is perfectly integrated with the world market such that world factor covariance can measure exactly the expected excess returns for that asset [Stulz (1981)]. Research into the integration level of ESMs has concluded that these markets are less than perfectly integrated [Bekaert and Harvey (1995)].

If we accept that markets are not perfectly integrated, especially in relation to ESMs, then it is likely that a number of pricing factors may be relevant. There are various theories that propose links between macroeconomic variables and stock market returns [Homa and Jaffee (1971); Mandelker and Tandon (1985); Boudoukh and Richardson (1993)]. Indeed, macroeconomic variables are often used to proxy for pervasive risk factors in the context of APT models [Chen, Roll and Ross (1986); Burmeister and McElroy (1988)].

Multifactor models such as the International Arbitrage Pricing Theory (IAPT) have been developed as an alternative to the ICAPM. Two main variants of the multifactor model have been proposed. The first variant implicitly assumes perfect integration, and models returns as a linear relation to a number of global risk sources [eg. Ferson and Harvey (1994); Dumas and Solnik (1995); Harvey (1995a)]. For instance, Ferson and Harvey (1994) use a multifactor model comprised of global risk factors and apply it to stock return indices of eighteen devebped markets over the period 1970 to 1989 . They find that a four-factor model consisting of the world market return, a world currency-risk factor, the change in the long-term expected inflation, and a world oil factor is able to explain an average of $36 \%$ of equity return variation. A number of other studies examine the ability of macroeconomic variables to explain stock return variation [eg. Homa and Jaffee (1971); Gultekin (1983); Keim and Stambaugh (1986); Harris and Opler (1991)], but these researchers have predominantly focussed on developed stock markets (DSMs).

There is limited research in the context of ESMs other than Harvey (1995a) who tests the relationship between ESM returns and a number of global risk factors. Harvey proxies these 
factors by world inflation, world GDP, world oil prices and a trade-weighted world exchange rate and finds that ESM returns exhibit only limited exposure to these factors.

The second type of multifactor model assumes complete segmentation whereby returns are assumed to be determined solely by a number of local priced factors [eg. Merton (1973); Ross (1976); Chen, Roll and Ross (1986); Jorion (1991); Ely and Robinson (1997)]. Ely and Robinson (1997) examine the relationship between quarterly stock returns and industrial production, consumer prices, money supply and GDP for sixteen DSMs over 1957 to 1992. For eleven of the sixteen markets examined, there existed at least one cointegrating relation, suggesting that a long term relationship between these variables and stock returns may exist. As an illustration in an emerging market, Bailey and Chung (1995) examine the Mexican stock market and find evidence that the exchange rate against the US dollar and the return spread between US and Mexican debt are able to explain a large proportion of the equity return variation in this market. There are other examples of research that has examined the relationship between local macroeconomic variables and stock returns in ESMs, but they have done so in respect of individual markets. [eg. India Darrat and Mukherjee (1987); Philippines - Bailey and Chung (1996); Zimbabwe - Oyama $(1997)]^{2}$.

From the above discussion, the difference between the two multifactor approaches is driven by assumptions about the level of integration. This in turn affects the selection of global versus local priced factors.

\section{Method}

In general, consider a model of equity return variation for country $i$, where country $i$ is perfectly integrated with world financial markets. It is assumed that there are N-Factors that are able to account for the variation in the returns for country i. ${ }^{3}$ The empirical (and ex-post) form of this model is described by equation (1):

$$
\mathrm{R}_{\mathrm{it}}=\alpha_{\mathrm{i}}+\sum_{\mathrm{m}=1}^{\mathrm{N}} \beta_{\mathrm{im}} \mathrm{F}_{\mathrm{mt}}^{\mathrm{W}}+\varepsilon_{\mathrm{it}}
$$

\footnotetext{
2 These papers are discussed in more detail in the next section of the paper.

3 The purpose of this paper is to examine which factors are able to explain the variation in ESM equity returns, rather than to propose a model of expected returns. Whether the factors we examine are priced (ie. have a positive associated risk premium) is beyond the scope of the paper.
} 
where:

$\mathrm{R}_{\mathrm{it}}$ is the return for the i'th country at time $t$,

$\beta_{\mathrm{im}}$ is the exposure of the i'th asset to the m'th risk factor,

$\mathrm{F}^{\mathrm{w}}{ }_{\mathrm{mt}}$ is the realization of the m'th risk factor at time $\mathrm{t}$.

$\varepsilon_{\mathrm{it}}$ is the residual term for country $i$ at time $t$.

Equity returns are assumed to be a linear relation to $\mathrm{N}$ global risk factors. If one global risk factor is identified (ie. $\mathrm{N}=1$ ) and this factor is assumed to be the return on the world market, then equation (1) collapses to the International Market Model. ${ }^{4}$

An alternative model can also be developed for returns in a country that is perfectly segmented from global markets. The variation in equity returns for country $i$ is assumed to be able to be explained by $\mathrm{K}$-factors, as described in equation (2):

$$
\mathrm{R}_{\mathrm{it}}=\alpha_{\mathrm{i}}+\sum_{\mathrm{j}=1}^{\mathrm{K}} \gamma_{\mathrm{ij}} \mathrm{F}_{\mathrm{ijt}}^{\mathrm{L}}+\mu_{\mathrm{it}}
$$

where:

$\mathrm{R}_{\mathrm{it}}$ is the return for the i'th country at time $\mathrm{t}$,

$\gamma_{i j}$ is the exposure of the i'th asset to the j'th risk factor,

$\mathrm{F}^{\mathrm{L}}{ }_{\mathrm{ijt}}$ is the is the realization of the $\mathrm{j}^{\prime}$ th risk factor in the $\mathrm{i}^{\prime}$ th country at time $\mathrm{t}$.

$\mu_{\mathrm{it}}$ is the residual term for country $\mathrm{i}$ at time $\mathrm{t}$.

Empirical studies in the area of market segmentation document two major findings. First, ESMs tend to be only partially integrated [Stehle (1977)]. Second, the level of integration appears to vary over time [Divecha, Drach and Stefek (1992); Bekaert and Harvey (1995); Harvey (1995b)]. In light of these findings, both global and local risk sources may be important in determining equity return variation. Equation (3) models equity returns as a function of exposure to both global and local factors:

$$
\mathrm{R}_{\mathrm{it}}=\alpha_{\mathrm{i}}+\sum_{\mathrm{m}=1}^{\mathrm{N}} \beta_{\mathrm{im}} \mathrm{F}_{\mathrm{mt}}^{\mathrm{W}}+\sum_{\mathrm{j}=1}^{\mathrm{K}} \gamma_{\mathrm{ij}} \mathrm{F}_{\mathrm{ijt}}^{\mathrm{L}}+\varepsilon_{\mathrm{it}}
$$

\footnotetext{
${ }^{4}$ The International Market Model can be viewed as the empirical analog of the single-factor International Capital Asset Pricing Model (ICAPM) developed by Solnik (1974).
} 
In (3), returns are now assumed to be a function of $\mathrm{N}$ global factors and $\mathrm{K}$ local factors ${ }^{5}$. It has been suggested within Harvey (1995), and also Bekaert (1995), that a country's integration level will determine the relative importance of the global and local factors. High (low) integration should result in high exposures to global (local) factors ${ }^{6}$. The focus in the paper is on equation (3).

We assume a single-factor specification to model global systematic risk ${ }^{7}$. Hence, in (3) we propose that $\mathrm{N}=1$. More specifically we assume that global risk is encapsulated in some valueweighted world index return. The determination of the set of local risk factors is more difficult given the lack of prior research in this area.

In general, the number of factors that influence equity returns has been a source of much contention. Throughout the APT literature, factor analysis has been used to identify common factors in both international and domestic returns. Trzcinka (1986) finds five dominant factors within returns for a sample of US firms. Cho (1984) uses inter-battery factor analysis on a range of US industries and documents that the number of factors ranges from between two and five. Cho, Eun and Senbet (1986) perform a similar analysis at the international level for eleven industrial economies and report between one and five factors. ${ }^{8}$

The extant literature suggests that a wide range of factors may be relevant. Such variables include goods prices, money supply, real activity, exchange rates, interest rates, political risk, oil prices, the trade sector, and regional stock market indices. However, in emerging markets, there is argument that not all of these variables are either relevant or appropriate. For instance, studies incorporating interest rates have found that it is not the interest rate itself that is relevant but the yield and default spread are more likely to influence equity returns [Chen, Roll and Ross (1986)]. Yet, in many emerging markets, there is not an active secondary market for bond issues and government paper. Political risk indices and oil prices have been show $\mathrm{n}$ to be only weakly correlated with ESM returns [Harvey (1995a); Erb, Harvey and Viskanta (1996)]. Regional influences are expected to be incorporated into returns if countries are integrated regionally, but

\footnotetext{
${ }^{5}$ Such a mixed global-local multifactor model is considered in Bekaert (1995) and Bekaert and Harvey (1995). The advantage of this model is that it can incorporate the fact that most emerging markets are neither fully integrated nor fully-segmented.

${ }^{6}$ Bekaert (1995) finds that high exposure to the world market return is indicative of a high level of integration.

${ }^{7}$ The assumption of a single global risk source is consistent with the ICAPM of Solnik (1974). This model has been applied to ESM returns in Buckberg (1995) and Harvey (1995a).

${ }^{8}$ In Cho et al (1986), developed markets are examined including Australia, Canada, France, Germany, Hong Kong, Japan, Netherlands, Singapore, Switzerland, United Kingdom, USA.
} 
the theoretical justification for the empirical link is limited. Moreover, any such link is likely to be driven by fundamental macro factors and a regional index is only useful to the extent that it captures the underlying fundamentals. Hence, at this stage, these variables are excluded from the initial analysis.

In light of the above considerations, the model utilises five factors: one global risk factor (the return on a value-weighted world market index) and four local risk factors proxied by macroeconomic variables (money supply, goods prices, real activity and exchange rates). ${ }^{9}$ Note that the use of a five-factor model is generally consistent with the APT literature with regard to the number of factors present in asset returns [eg. Cho, Eun and Senbet (1986); Trzcinka (1986)].

Hence, the reduced form of the model can be written as:

$$
\mathrm{R}_{\mathrm{it}}=\alpha_{\mathrm{i}}+\beta_{\mathrm{i}} \mathrm{R}_{\mathrm{wt}}+\delta_{\mathrm{i}} \mathrm{MS}_{\mathrm{it}}+\phi_{\mathrm{i}} \mathrm{GP}_{\mathrm{it}}+\gamma_{\mathrm{i}} \mathrm{RA}_{\mathrm{it}}+\lambda_{\mathrm{i}} \mathrm{ER}_{\mathrm{it}}+\varepsilon_{\mathrm{it}}
$$

where:

$\mathrm{R}_{\mathrm{it}}$ is the return for the i'th country at time $t$,

$\mathrm{R}_{\mathrm{wt}}$ is the return on a value-weighted world market index at time $\mathrm{t}$

$\mathrm{MS}_{\mathrm{it}}$ is the percentage change in a money supply variable for country $\mathrm{i}$ at time $\mathrm{t}$

$\mathrm{GP}_{i t}$ is the percentage change in a goods price variable for country $i$ at time $t$

$\mathrm{RA}_{\mathrm{it}}$ is the percentage change in a real activity variable for country $i$ at time $t$

$E R_{i t}$ is the percentage change in a exchange rate variable for country $i$ at time $t$

In equation (4), all variables are measured contemporaneously with returns. Hence, there are no expectations in the model and there is an implicit assumption of contemporaneous association. However, consideration must also be given to time delays in the production of information concerning the macroeconomic variables and the transmission and incorporation of that information into stock market prices. It is possible that reporting delays create a lag between the observation of data concerning a macroeconomic variable and the incorporation of that information into prices.

As a result, two models are proposed. The first model is the contemporaneous model as presented in (4) above which implicitly assumes an immediate impact of macroeconomic information on

\footnotetext{
${ }^{9}$ There is argument for the inclusion of many other variables in addition to, or instead of, the selected four variables here. However, this is an unavoidable problem associated with this area of research (Fama, 1991). In this case, we have balanced the theoretical propositions and prior evidence to select the factors. Nevertheless, the potential impact of other variables is explored later in the paper.
} 
stock returns. The second model lags the explanatory variables to incorporate delays in the release of information. As a proxy for the release delays of the macroeconomic data, the timeliness guides published by the International Monetary Fund (IMF) Data Dissemination Standards ${ }^{10}$ are used. Data for the world market return and exchange rates are available on a daily basis, therefore these variables appear contemporaneously in the second model. Following IMF advice, money supply and goods prices are lagged by one month, and real activity by two months.

Hence, using monthly return intervals, the lagged model can be written as:

$$
\mathrm{R}_{\mathrm{it}}=\alpha_{\mathrm{i}}+\beta_{\mathrm{i}} \mathrm{R}_{\mathrm{wt}}+\delta_{\mathrm{i}} \mathrm{MS}_{\mathrm{it}-1}+\phi_{\mathrm{i}} \mathrm{GP}_{\mathrm{it}-1}+\gamma_{\mathrm{i}} \mathrm{RA}_{\mathrm{it}-2}+\lambda_{\mathrm{i}} \mathrm{ER}_{\mathrm{it}}+\varepsilon_{\mathrm{it}}
$$

where $\mathrm{t}$ is measured in months.

Asset pricing models such as the APT advocate that only the expected component (ie. innovations) of the variables in models (4) and (5) will be related to expected returns. However, as mentioned previously, the focus of this paper is upon explaining the variation in realised, rather than expected, returns. As such the independent variables used are expressed in 'raw' form. Hence, the variables contain both an expected and an unexpected component. Further, given the large number of markets (and variables) being examined, it is not feasible to generate expectations for each variable in every market ${ }^{11}$.

There are several theoretical justifications to expect a relationship to exist between the macroeconomic variables in (5) and stock returns. Exploring each variable in turn, Monetary Portfolio Theory suggests that changes in money supply alters the equilibrium position of money, thereby altering the composition and price of assets in an investor's portfolio [eg. Cooper (1974); Rozeff (1974)]. In addition, changes in money supply may impact on real economic variables, thereby having a lagged influence on stock returns [Rogalski and Vinso (1977)]. Both of these mechanisms suggest a positive relationship between changes in money supply and stock returns.

Common stock is traditionally viewed as a hedge against inflation, due to the fact that equity represents a contingent claim on the realm assets of the firm. In the presence of inflation, the value of the contingent claims will be revised upward. Therefore, proportionate increases in prices should not affect the real rates of return on equity [Day (1984)]. However, the monetary assets of the firm (ie. cash, securities, receivables and debt) will be independent of fluctuations in

${ }^{10}$ These standards are contained in the IMF's 1996/97 Annual Report.

11 This issue is more clearly illustrated in the context of model (6) below. 
the price level. Hence, it is only the real component of the firm that will be hedged against changes in inflation [Hong (1977)]. Surprisingly, empirical tests have found a negative relationship to exist between inflation and nominal stock returns [Fama and Schwert (1977); Gultekin (1983)]. In light of the lack of agreement between the theory and evidence, it is diffic ult to predict the direction of the relationship between stock returns and inflation in ESMs. This is particularly so for some of the Latin American countries which have experienced periods of high inflation over our sample period.

It is widely accepted that current stock levels are positively related to future levels of real activity, as measured by GDP or industrial production. Intuitively this finding seems justified since returns are a function of the future cash flow stream, which is highly dependent upon future economic conditions. However, a number of studies have documented a relationship between past (or current) production and stock returns [Fama (1984); James, Koreisha and Partch (1985); Schwert (1990); Harris and Opler (1990); Ferson and Harvey (1996)]. Fama (1984) found a relationship between concurrent measures of US stock returns and industrial production that was positive and highly significant. James, Koreisha and Partch (1985) investigated the relationship between the lagged change in US industrial production and the return on the S\&P 500 index using monthly data from 1962 to 1981. They found that current stock returns were related to industrial production lagged by two periods. We therefore expect, a priori, real activity to be positively related to equity returns.

Under perfect purchasing power parity conditions, exchange rates will adjust to reflect relative inflation levels, and the law of one price will be upheld. Hence, exchange rate risk will not be separately priced. However, in the short-to-medium term, deviations from PPP have been reported for a number of industrial countries [Stockman (1980); Adler and Lehman (1983); Frenkel (1981)]. Under these conditions, deviations from purchasing power parity will be priced to the extent that they represent exchange rate risk that must be borne by investors [Jorion (1991); Dumas and Solnik (1995)]. Therefore, an exchange rate variable is included as a local risk factor.

Macroeconomic variables similar to those in equation (5) have been used in a number of ESM studies. However, as mentioned previously, these studies have focussed on a single ESM. Bailey and Chung (1995) found that the exchange rate against the US dollar was able to explain a significant amount of the variation in monthly Mexic an equity returns over the 1986 to 1994 period. Bailey and Chung (1996) also examine the Philippine equity market over the 1982 to 1993 period. Regressions of monthly returns against a country return index, the exchange rate per US dollar, the black market exchange rate premium, and a credit risk variable were able to 
explain an average of thirty-five percent of return variation across industries. Darrat and Mukherjee (1987) found a causal relationship between annual Indian stock returns and a number of macroeconomic variables over the 1948 to 1984 period. They found evidence of a relationship between returns and changes in money supply, the price level and long-term interest rates. Oyama (1997) used Principal Components Analysis (PCA) to identify the sources of monthly return variation in the Zimbabwe stock market. The principal components were found to be significantly correlated with the variables money supply, short-term interest rates, commodity prices and an exchange rate variable. A multifactor model incorporating these 4 variables was able to explain an average of forty percent of the return variation in this market.

We recognise that the selection of the four local macroeconomic variables is not perfect and that cases can be made for the inclusion of other factors. Moreover, the proxies almost surely contain measurement error. Hence, we do not propose that (4) and (5) are complete models. It may be that the markets do indeed have common exposures but the models in (4) and (5) are not capable of establishing those exposures. Consequently, we propose a further test for commonality in exposures that involves the extraction of relevant pricing factors from principal components analysis.

This test involves three steps. First, for each market, a number of variables are identified that are able to explain a 'significant' portion of return variation for that market. Second, from these variables a number of factors are extracted by principal components analysis (PCA). Third, these factors are then regressed against the equity returns for each market, and a test is performed to determine to which factors the markets have similar exposures. This analysis allows a determination of common priced factors (if any).

The a priori selection of variables for the PCA analysis commences with the earlier identified variables, ie. money supply, goods prices, real activity and exchange rates. These variables are augmented by other variables proposed in the literature. The additional variables include a country (political) risk measure (CR), the trade sector (TS), interest rates (IR) and regional market indices (RI). ${ }^{12,13}$ Further, given that this method is an attempt to extract factors from the 'relevant'

\footnotetext{
${ }^{12}$ For each country an equally-weighted regional index is formed excluding that particular country's returns.

${ }^{13}$ The country risk (CR) variable is a qualitative variable supplied by Political Risk Services incorporating political risk $(50 \%)$, financial risk $(25 \%)$ and economic risk $(25 \%)$. The variable ranges from 0 (highly country risk) to 100 (low country risk). The trade sector (TS) is proxied by the size of the trade sector (ie. exports plus imports) as a proportion of GDP. For each ESM, the deposit rate was used for the interest rate (IR). Where the deposit rate was unavailable, an interest rate was selected that was the most unregulated.
} 
information, we also include the microeconomic effects captured by price-to-earning ratios (PE) and dividend yields (DY) as these have been previously suggested as relevant. ${ }^{14}$ Consequently, for each market, the following regression is then fitted:

$$
\mathrm{R}_{\mathrm{it}}=\alpha_{\mathrm{i}}+\beta_{\mathrm{i}} \mathrm{R}_{\mathrm{mt}}+\delta_{\mathrm{i}} \mathrm{MS}_{\mathrm{it}}+\phi_{\mathrm{i}} \mathrm{GP}_{\mathrm{it}}+\gamma_{\mathrm{i}} \mathrm{RA}_{\mathrm{it}}+\lambda_{\mathrm{i}} \mathrm{ER}_{\mathrm{it}}+\chi_{\mathrm{i}} \mathrm{CR}_{\mathrm{it}}+\eta_{\mathrm{i}} \mathrm{TS}_{\mathrm{it}}+\varphi_{\mathrm{i}} \mathrm{IR}_{\mathrm{it}}+\kappa_{\mathrm{i}} \mathrm{RI}_{\mathrm{it}}+\mu_{\mathrm{i}} \mathrm{PE}_{\mathrm{it}}+v_{\mathrm{i}} \mathrm{DY}_{\mathrm{it}}+\varepsilon_{\mathrm{it}}
$$

From the above regression, PCA condenses the variables in each market into a smaller set of common factors. As discussed above, the extracted factors are then used to test commonality in exposure across markets and by region.

\section{Data}

There is no clear definition of what constitutes an 'emerging stock market'. We classify stock markets as emerging through the listing adopted by the International Finance Corporation (in IFC 'Emerging Markets Factbook' 1997). The IFC provide data on 27 emerging markets. ${ }^{15}$ This study incorporates 20 of these markets including six Latin American countries (Argentina, Brazil, Chile, Colombia, Mexico and Venezuela), six Asian countries (India, Malaysia, Pakistan, Philippines, Taiwan and Thailand), one European country (Greece), one Middle Eastern country (Jordan) and two African countries (Nigeria and Zimbabwe).

The emerging market return data are obtained from the International Finance Corporation (IFC). The sample period used for this study spans January 1985 through December 1997. Although return data are available for some markets from 1976, the data may have been influenced by a 'back-filling' bias. ${ }^{16}$ All return data are calculated on a monthly return interval, include both dividend and capitalisation adjustments, and are expressed in continuously compounded form. In addition, all returns are measured in US dollars to negate the influence of domestic inflation. Hence, returns denominated in this form only retain US inflation and are consistent across markets. Expressing the returns in US dollars has the additional implication that returns are viewed from the perspective of an international investor rather than a local investor.

The regional index (RI) is an equally weighted index computed for each of Latin America, Asia and Europe. There we re only three ESMs from both Africa and the Middle East.

${ }^{14}$ For instance, albeit using a different approach, Chen (1991) reports that the use of the dividend-price ratio as a state variable in addition to the default spread, term spread, short-term interes $t$ rate and industrial production, appears to be a determinant of future stock returns.

${ }^{15}$ For this study at least five years of return data are required. Seven markets are subsequently eliminated due to insufficient data (China, Czech Republic, Hungary, Pen, Poland, South Africa and Sri Lanka).

${ }_{16}$ In constructing the database, the IFC selected stocks that were available at January 1985 and reconstructed the country indices for the prior years to 1976. The potential survivorship bias created by this procedure is discussed in Harvey (1995a). 
The proxy chosen for the world market index is the MSCI World Index (as used in Harvey (1995a) and Buckberg (1995)). The money supply and goods price data are from the IMF, with the exception of Taiwan (which is not a member of the IMF). Real activity ${ }^{17}$ and exchange rate ${ }^{18}$ variables are obtained from local sources. ${ }^{19}$ Each series is sampled monthly to correspond with the equity return interval.

Both Dickey-Fuller and Phillips -Perron unit root tests are used to examine the stationarity of each of the series. ${ }^{20}$ Time tends were included where significant. Both the return data and the percentage change in the macroeconomic variables are stationary for all countries. ${ }^{21}$

\section{Results}

Table 1 contains the results from fitting the model as described in (4) to each of the 20 emerging markets. A least squares procedure was used, with the coefficients being adjusted where necessary for serial correlation and/or heteroskedasticity. ${ }^{22}$ The results indicate that ESMs show little sensitivity to the return on the world market index, consistent with previous findings [eg. Harvey (1995a)]. Only eight markets display a significant coefficient on the world market. Of note these coefficients are positive as suggested by the ICAPM, indicating that increases in ESM returns are associated with increases in returns on the world market index.

The exchange rate variable is clearly the most influential macroeconomic variable, with the returns for twelve markets significantly related to this variable. ${ }^{23}$ The signs on the coefficients on the exchange rate variable are predominantly negative, which is consistent with the analysis being

\footnotetext{
${ }^{17}$ For some countries an industrial production index was unavailable and a manufacturing production index was used instead.

${ }^{18}$ The selected exchange rate series was a trade-weighted index for each country. The exchange rate for the national currency against the US dollar was used where the index series was unavailable.

19 The macroeconomic variables are not seasonally adjusted, as these types of data are generally unavailable in emerging markets. Moreover, as in Chen (1991), the use of seasonally unadjusted data avoids the use of future data which is an important consideration for any ex-ante implications that may be drawn.

${ }^{20}$ More weight was given to the Phillips-Perron unit root tests as this test has been shown to be more reliable than Dickey-Fuller tests in the presence of large amounts of heteroskedasticity [Banerjee et al (1993)].

21 Tests performed on the correlation matrix of the macroeconomic variables indicated no significant correlation.

${ }_{22}^{2}$ These methods are discussed in Newey and West (1987) and White (1980).

${ }^{23}$ The regression was also performed using returns expressed in local dollars. Under this analysis, the exchange rate variable remained significant for eight markets. This result suggests that the relationship between returns and exchange rate changes in these markets is robust to the currency denomination of returns.
} 
conducted from an international investor's perspective. For instance, a devaluation of the domestic currency will result in an increase in US dollar denominated returns. This result is consistent with work of Adler and Dumas (1983) who argue that deviations from PPP necessitate the inclusion of an exchange rate factor. The remaining macroeconomic variables all perform relatively poorly. The money supply variable is significant in four markets (mainly positive as expected), real activity in two markets and goods prices in only one market. The final column of Table 1 contains an F-test of the null hypothesis that all of the coefficients on the macroeconomic variables (ie. money supply, goods prices, real activity and exchange rate) are jointly equal to zero. Failure to reject the null suggests that the model fails to perform better than the single global risk factor International Market Model (IMM). This null hypothesis is rejected for eleven of the twenty markets. Hence, in summary the evidence is not conclusive of dominance of either the single global factor model or the multifactor local factor model. The $\mathrm{R}^{2}$ values range considerably from almost no explanatory power to a high of $38 \%$ in the case of Malaysia. Notably, the higher explanatory power tends to occur in the Asian markets. The results indicate a lack of uniformity across markets.

$* * * * * * * * * * * * * * * * * * * * * * * * * * * * * * *$

Table 1 about here

$* * * * * * * * * * * * * * * * * * * * * * * * * * * * * * *$

Table 2 presents the results from fitting the lagged model in (5) that incorporates delays in information release dates for the macroeconomic variables to each of the 20 emerging markets. The results are similar to those obtained from fitting the contemporaneous model in Table 1. The significance on the global risk factor generally remains stable and is significant in ten markets.

Comparing Tables 1 and 2, the money supply variable improves when information release dates are considered. Six markets exhibit a significant relationship between equity returns and lagged money supply. The exchange rate is again significant in twelve markets, however its sign is variable. Goods prices and real activity appear to play little role. The F-test of joint significance of the macroeconomic variables is similar to that for the contemporaneous model with ten markets rejecting the null hypothesis. Again, the results appear to indicate a degree of uniqueness.

Overall, the results from Tables 1 and 2 suggest that the macroeconomic variables representing goods prices and real activity have only limited ability to explain the variation in returns. Money supply has greater importance, particularly when information release delays are taken into 
consideration. The most significant variables from the analysis are the exchange rate variable and the return on the world market index.

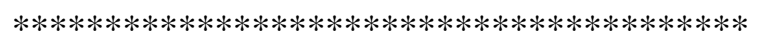

Table 2 - about here

$* * * * * * * * * * * * * * * * * * * * * * * * * * * * * * * * * * * * * * * * *$

From the analysis to date, the determination of macroeconomic variables to explain equity return variation in emerging markets appears to be a difficult task. Given that neither the global risk factor nor the local risk factors clearly dominate (as evidenced by the range in F-tests in Tables 1 and 2), it appears that each market should be treated differently. However, several explanations are possible. First, our proxies may be poor. Second, while care has been taken to account for information lags (as in Table 2), these adjustments will not be precise. Information lags and the degree of market efficiency with respect to the release and incorporation of information content will vary across markets. Third, the model may be mis-specified and almost certainly suffers from unidentified omitted factors. These criticisms are inherently difficult to address, and indeed the latter criticism applies more generally to multifactor studies. Hence, we now examine an alternative approach to further investigate whether the variation in returns can be explained by similar factors. Moreover, the additional test involving PCA factor extraction seeks to determine whether emerging market returns have similar exposure to factors.

The model in (3) is now augmented with additional factors (representing country risk, trade sector, interest rates, a regional index, dividend yield and price-to-earnings ratio) as in (6). These factors represent a wider information set from which the PCA can draw upon. The purpose of PCA is to condense the variables that explain the return variation in each market into a smaller set of common factors. All variables from (6) are initially included in the analysis. ${ }^{24}$ In relation to the regional indices, four equatweighted regional indices are included (Latin America, Asia, Europe and a combined Middle East and Africa). ${ }^{25}$

\footnotetext{
${ }^{24}$ While the importance of each variable varies between markets, the loss in efficiency from including less relevant variables is expected to be much less than the loss from excluding relevant variables. After performing the PCA, less relevant variables should have only small loadings on the significant factors.

${ }_{25}$ The Middle East and Africa are combined as one region due to the small number of markets in these two areas.
} 
The results from fitting (6) are presented in Table $3 .^{26}$ The global risk factor loses much of its significance when compared to Tables 1 and 2. The significance of the macroeconomic variables is spread with the exchange rate again exhibiting the greatest occurrence of significance. The results also indicate the presence of a strong regional factor with the regional market index being significant and positive in a number of markets. ${ }^{27}$ However, it is the microeconomic variables that stand out in Table 3. The price-to-earnings variable is significant and positive in seventeen markets. This supports previous evidence that these ratios have been found $\mathbf{b}$ increase greatly with financial liberalisation and increased capital flows [Bekaert (1995) and Buckberg (1995)]. Similarly the dividend yield is significant in sixteen markets and is consistently of positive sign. The model provides quite high explanatory power with an average R-square of 59\%. However, we do not place emphasis on the results in Table 3 due to the large number of variables and the obvious criticism of data mining. Rather, Table 3 provides the background for the PCA analysis.

$* * * * * * * * * * * * * * * * * * * * * * * * * * * * * * * * * * * * * * * *$

Table 3 - about here

$* * * * * * * * * * * * * * * * * * * * * * * * * * * * * * * * * * * * * * * *$

The composition and extraction of components is heavily biased towards those variables with the greatest variability [Nunally (1978)]. The descriptive statistics generated for the variable set indicate a large disparity in terms of variance. ${ }^{28}$ The PCA is therefore performed using the correlation matrix. This effectively gives each variable an equal weighting in the data matrix, independent of their variance. The components are rotated using the varimax method as suggested by Kaiser (1958) to facilitate interpretation. Identification of the scree plot resulted in four principal components being selected. The variable loadings on the four components are contained in Table 4.

By averaging the factor loadings on each variable, interpretation may be given to the general economic forces represented by each component. Both real activity and the size of the trade sector appear to load positively onto the first component. This suggests that the first component may proxy for the level of economic activity. The second component has high positive loadings for both money supply and trade sector, perhaps being representative of consumption. The third

\footnotetext{
${ }^{26}$ When estimating the regression in (6), some data are unavailable in the early years, hence the sample size is reduced.

${ }^{27}$ Note again that the country's own returns are excluded from the construction of the regional index so to avoid induced correlation.

28 This is especially evident when comparison is made between the goods price (high variability) and exchange rate (low variability) variables in Latin America markets.
} 
component appears to relate to country risk and hence might be thought of as a political risk influence. The fourth component represents global effects. The microeconomic variables of priceto-earnings and dividend yield also load heavily onto this factor, consistent with the findings of Bekaert (1995) that microeconomic effects may be sensitive to market liberalisations. ${ }^{29}$ However, as with any PCA, the comments offered here are speculative.

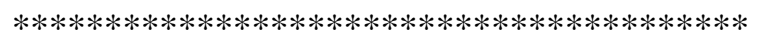

Table 4 - about here

************************************************

Table 5 contains the results from a regression of the returns against the four identified principal components. The $\mathrm{R}^{2}$ values are relatively high, which suggests that there may be some commonality in the determinants of returns. The model fit ranges from a low of $2 \%$ in Venezuela to $45 \%$ in Indonesia, and are generally around or above $20 \%$. The results also indicate a number of significant coefficients, particularly for the Asian markets.

These results suggest that while emerging markets are typically viewed as being unique, as indeed our earlier analysis also suggests, a set of four principal components is able to consistently explain equity return variation across the markets under examination. An implication that follows is that it may be beneficial to diversify fund portfolios across regions rather than across markets.

$* * * * * * * * * * * * * * * * * * * * * * * * * * * * * * * * * * * * * * * * * *$

Table 5 - about here

$* * * * * * * * * * * * * * * * * * * * * * * * * * * * * * * * * * * * * * * * *$

The commonality in the determinants of the returns does not suggest that the relevant factors are the same for every market. Returns will differ between markets to the extent that they exhibit different exposures to each of the principal components. If we make the assumption that the principal components proxy for the 'true' source of return variation for all markets, ${ }^{30}$ we can establish the exact source of any return differences between markets. These return differences will be evident if for any principal component, the null hypothesis that each market has identical coefficients on that component is rejected.

\footnotetext{
29 Bekaert (1995) and also Buckberg (1995) found that price-to-earnings ratios increased while dividend yields decreased around capital market liberalisation dates.

${ }^{30}$ The assumption may be reasonable given the high explanatory power of the four principal components.
} 
Table 6 Panel A contains the results from an F-test of identical exposure across markets to each principal component. No commonality is evident when all twenty markets are considered collectively. However, common exposure to the components is evident when regions are examined. The Latin American markets display the strongest regional commonality. These markets have similar coefficients on three of the four components, namely the first, second and third components. However, this result may be a product of the poor explanatory power of the four principal components in Latin American markets, which would result in each of these markets displaying no exposure to each of the components. The returns for the Asian countries exhibit similar exposure to the first and perhaps the fourth components. Commonality is most evident for European markets, where there are similar coefficients for each of the four components. Surprisingly given the odd mix of the 'Other' group, it exhibits similar exposure to the second and third components but again this commonality could be commonality of no exposure.

Table 6 Panel B reports an F-test of whether the exposure to a given factor is jointly zero across all countries ${ }^{31}$. Failure to reject the null implies that the factor is independent of the country returns. This hypothesis is rejected in all but two cases- the third component for the Europe region and the fourth component for the 'other' region. The result from this table suggests that the model compris ing the four (factors) components may be correctly specified. These results also illustrate the generality of the four components, in that the components are significantly related to returns in each of the four regions considered.

\footnotetext{
$* * * * * * * * * * * * * * * * * * * * * * * * * * * * * * * * * * * * * * * *$

Table 6 Panel A - about here

************************************************
}

The finding of commonality has important implications for both international investors and for international asset pricing. As discussed previously, diversification benefits are greatest when the factors driving returns in each country are uncorrelated. However, for international investors, the observed commonality represents a limit to the diversification benefits available from investing in emerging markets, despite their apparent uniqueness. Moreover, the commonality within regions but not across the aggregated group of all markets suggests that diversification across regions, but not within regions, is a sound strategy.

${ }^{31}$ See Kan and Zhang (1999) for a discussion of the implications of including 'useless' factors in a multivariate regression. 


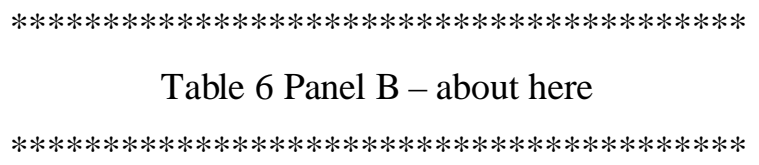

Table 6 Panel B - about here

Finally, as noted above, the commonality in exposures may indeed be commonality of no exposure. The final test involves a pooled regression of returns on the extracted principal components. The results are presented in Table 7 and are quite compelling. For the aggregated set of markets and for each of the three main regions (Latin America, Asia and Europe) there are significant coefficients on all four components. This result provides supportive evidence that regional factors appear particularly relevant. Table 7 further supports the proposition that the commonality in exposures is non-zero. In the case of the 'Other' group, there is significance on only one component. This latter result is expected given the earlier results and the fact that this group comprises the residual and non-regional markets.

$* * * * * * * * * * * * * * * * * * * * * * * * * * * * * * * * * * * * * * * * *$

Table 7 - about here

*********************************************

\section{Conclusions}

A number of studies have found that a relationship exists between macroeconomic variables and equity market returns. Further the APT literature suggests that macroeconomic variables may proxy for pervasive risk factors. This paper extends the literature by considering the relationship within an emerging markets context. We propose a multifactor model for country returns that incorporates the country's degree of integration, thereby allowing both global and local risk factors to influence returns. Global factors are proxied by the world market return and local factors by a set of macroeconomic variables. We use the variables money supply, inflation, industrial production and exchange rates, and find some evidence that these variables are significant in their association with emerging equity returns above that explained by the world factor. When a larger set of variables is considered the explanatory power of the model substantially improves such that it is able to explain a large amount of the return variation for most emerging markets. The microeconomic effects of price-to-earnings and dividend yield are most apparent. This evidence appears to point to a model where local factors are most relevant such that commonality in exposures across markets is not expected. 
Nevertheless, the paper makes use of this set of variables to investigate the degree of commonality between emerging equity market returns. A number of principal components are extracted and regressed against returns for each market. We find that emerging market returns indeed have similar exposures to a number of these factors. Commonality is particularly evident when regions are considered.

The finding of commonality in exposures across markets has implications for international investors as it suggests a limitation to diversification, concentrated particularly at the regional level. These results are relevant when it is considered that many investors gain access to emerging markets via portfolios (ie. mutual funds). The results suggest that investors should diversify across specialised regional funds. The findings also have implications for international asset pricing models applied to emerging markets. These models should not only consider a country's level of integration with world financial markets, but should also cater for a country's level of regional integration. 


\section{References}

Adler, M. and B. Dumas, 1983, International portfolio choice and corporation finance: A synthesis, Journal of Finance 38, 925-984.

Adler, M. and B. Lehmann, 1983, Deviations from purchasing pwer parity in the long run, Journal of Finance 38, 1471-1487.

Bailey, W. and Y.P. Chung, 1995, Exchange rate fluctuations, political risk and stock returns: Some evidence from an emerging market, Journal of Financial and Quantitative Analysis, 30, 541-562.

Bailey, W. and Y.P. Chung, 1996, Risk and return in the Philippine equity market: A multifactor exploration, Pacific-Basin Finance Journal, 4, 197-218.

Banerjee, A., J. Dolado, J. Galbraith and D. Hendry, Co-integration, error correction, and the econome tric analysis of non-stationary data, Oxford University Press, 1993.

Bekaert, G., 1995, Market integration and investment barriers in emerging equity markets, World Bank Economic Review 9, 75-107.

Bekaert, G. and C. Harvey, 1995, Time-varying world market integration, Journal of Finance 50, 403-444.

Boudoukh, J. and M. Richardson, 1993, Stock returns and inflation: A long-horizon perspective, American Economic Review, 83, 1346-1355.

Brown, S.J. and T. Otsuki, 1990, "Macroeconomic factors and the Japanese equity markets: the CAPMD project." In Edwin J. Elton and Martin J. Gruber (eds) Japanese Capital Markets. New York: Harper and Row.

Buckberg, E., 1995, Emerging stock markets and international asset pricing, World Bank Economic Review 9, 51-74.

Burmeister, E. and M. McElroy, 1988, Joint estimation of factor sensitivities and risk premia for the Arbitrage Pricing Theory, Journal of Finance 38, 721-735.

Chen, N.F., 1991, Financial investment opportunities and the macroeconomy, Journal of Finance 46, 529-554.

Chen, N.F., R. Roll and S.A. Ross, 1986, Economic forces and the stock market, Journal of Business, 59, 383-403.

Cho, D.C., 1984, On testing the arbitrage pricing theory: Inter-battery factor analysis, Journal of Finance, 39, 1485-1502.

Cho, D.C., C.S. Eun and L.W. Senbet, 1986, International arbitrage pricing theory: An empirical investigation, Journal of Finance 41, 313-329.

Claessens, S., S. Dasgupta and J. Glen, 1993, Return behaviour in emerging stock markets, World Bank Economic Review 9, 131-152.

Cooper, R.V., 1974, Efficient capital markets and the quantity theory of money, Journal of Finance 24, 887-921.

Darrat, A.F. and T.K. Mukherjee, 1987, The behaviour of the stock market in a developing country, Economics Letters 22, 273-278.

Day, T.E., Real stock returns and inflation, Journal of Finance 39, 493-502.

Divecha, A., J. Drach and D. Stefak, 1992, Emerging markets: a quantitative perspective, Journal of Portfolio Management 4, 41-50.

Dumas, B. and B. Solnik, 1995, The world price of foreign exchange risk, Journal of Finance 50, 445-479.

Ely, D.P. and K.J. Robinson, 1997, Are stocks a hedge against inflation? International evidence using a long-run approach, Journal of International Money and Finance, 16, 141-167.

Errunza, V., 1977, Gains from portfolio diversification in less developed countries' securities, Journal of International Business Studies 8, 83-89. 
Errunza, V., 1983, Emerging markets: a new opportunity for improving global portfolio performance, Financial Analysts Journal 39, 51-58.

Errunza, V. and E. Losq, 1985, International asset pricing under mild segmentation - theory and test, Journal of Finance 39, 105-124.

Errunza, V., E. Losq and P. Padmanabhan, 1992, Tests of integration, mild segmentation and segmentation hypotheses, Journal of Banking and Finance 16, 949-972.

Fama, E.F., 1991, Efficient capital markets: II, Journal of Finance 46, 1575-1617.

Fama, E.F. and G.W. Schwert, 1977, Asset returns and inflation, Journal of Financial Economics $5,115-146$.

Ferson, W. and C.R. Harvey, 1994, S ources of risk and expected returns in global equity markets, Journal of Banking and Finance 18, 775-803.

Frenkel, J.A., 1981, Flexible exchange rates, prices and the role of news: Lessons from the 1970s, Journal of Political Economy 89, 665-705.

Goetzmann, W.N. and Jorion, P., 1999, Re-emerging markets, Journal of Financial and Quantitative Analysis 34, 1-32.

Gultekin, N.B., 1983, Stock market returns and inflation: Evidence from other countries, Journal of Finance 38, 49-67.

Harris, T.C., and T.C. Opler, 1990, Stock market returns and real activity, UCLA Working Paper.

Harvey, C.R., 1993, Portfolio enhancement using emerging markets and conditioning information, in: Claessens, S. and S. Gooptu, eds, Portfolio investment in developing countries (World Bank Discussion Paper 228, Washington DC).

Harvey, C.R., 1995a, The risk exposure of emerging equity markets, World Bank Economic Review 9, 19-50.

Harvey, C.R., 1995b, Predictable risk and return in emerging markets, Review of Financial Studies 8, 773-816.

Hodrick, R., 1981, International asset pricing with time-varying risk premia, Journal of International Economics 11, 573-587.

Homa, K.E., and D.M. Jaffee, 1971, The supply of money and common stock prices, Journal of Finance, 26, 1045-1066.

International Finance Corporation, 1994, 1995, 1997 Emerging stock markets factbook (World Bank, Washington DC).

Jarque, C.M., and A.K. Bera, 1987, A test for normality of observations and regression residuals, International Statistical Review 55, 163-172.

Jorion, P., 1991, The pricing of exchange rate risk in the stock market, Journal of Financial and Quantitative Analysis 26, 363-376.

Kan, R. and C. Zhang, 1999, Two-pass tests of asset pricing models with useless factors, Journal of Finance, 54, 203-236.

Kandel, S. and R.F. Stambaugh, 1995, Portfolio inefficiency and the cross-section of expected returns, Journal of Finance 50, 157-184.

Kryzanowski, L., S. Lalancette and M.C. To, 1997, Performance attribution using an APT with prespecified macrofactors and time-varying risk premia and betas, Journal of Financial and Quantitative Analysis 32, 205-224.

Mandelker, G. and K. Tandon, 1985, Common stock returns, real activity, money and inflation: some international evidence, Journal of International Money and Finance 4, 267-286.

Newey, W. and K. West, 1987, A simple, positive semi-definite, heteroskedasticity and autocorrelation consistent covariance matrix, Econometrica 55, 703-708.

Nunally, J., 1978, Psychometric Theory, McGraw Hill.

Oyama, T., 1997, Determinants of stock prices: The case of Zimbabwe, IMF Working Paper, WP/98/117.

Pesando, J.E., 1974, The supply or money and common stock prices: Further observations of the econometric evidence, Journal of Finance 28, 908-922. 
Poon, S. and S.J. Taylor, 1991, Macroeconomic factors and the UK stock market, Journal of Business Finance and Accounting, 19, 619-636.

Priestley, R., 1996, The arbitrage pricing theory, macroeconomic and financial factors, and the expectations generating processes, Journal of Banking and Finance 20, 869-890.

Rogaliski, R.J. and J.D. Vinso, 1977, Stock returns, money supply and the directions of causality, Journal of Finance 32, 1017-1030.

Roll, R. and S. Ross, 1994, On the cross-sectional relation between expected returns and betas, Journal of Finance 49, 101-121.

Solnik, B., 1983, International arbitrage pricing theory, Journal of Finance 38, 449-457.

Stockman, A.C., 1980, A theory of exchange rate determination, Journal of Political Economy $88,673-698$.

Stulz, R., 1981, A Model of international asset pricing, Journal of Financial Economics 9, 383406.

Trzcinka, On the number of factors in the arbitrage pricing model, Journal of Finance 41, 347368.

White, H., 1980, A heteroskedasticity-consistent covariance matrix estimator and a direct test for heteroskedasticity, Econometrica 48, 817-838.

Wilcox, J.W., 1992, Global Investing in Emerging Markets, Financial Analysts Journal 15-19. 


\section{Table 1}

\section{Contemporaneous Model Estimated on Monthly Returns by Country February 1985 to December 1997}

$\mathrm{R}_{\mathrm{it}}=\alpha_{\mathrm{i}}+\beta_{\mathrm{i}} \mathrm{R}_{\mathrm{wt}}+\delta_{\mathrm{i}} \mathrm{MS}_{\mathrm{t}}+\phi_{\mathrm{i}} \mathrm{GP}_{\mathrm{it}}+\gamma_{\mathrm{i}} \mathrm{RA} \mathrm{A}_{\mathrm{it}}+\lambda_{\mathrm{i}} \mathrm{ER}_{\mathrm{it}}+\varepsilon_{\mathrm{it}} \ldots(4)$

\begin{tabular}{|c|c|c|c|c|c|c|c|c|c|}
\hline Country & $\begin{array}{c}\text { Sample } \\
\text { Start }\end{array}$ & $\alpha_{i}$ & $\beta_{\mathrm{i}}$ & $\delta_{1}$ & $\phi$ & $\gamma_{i}$ & $\overline{\lambda_{i}}$ & $\mathrm{R}^{2}$ & F-Test \\
\hline \multirow[t]{2}{*}{ Argentina } & Feb 85 & 0.032 & -0.296 & $0.242 *$ & -0.222 & -0.077 & -0.028 & 0.03 & 2.01 \\
\hline & & $(1.41)$ & $(-0.54)$ & $(2.67)$ & $(-0.92)$ & $(-0.55)$ & $(-0.75)$ & & {$[0.10]$} \\
\hline \multirow[t]{2}{*}{ Brazil } & Feb 85 & 0.018 & 0.698 & 0.142 & -0.134 & -0.101 & -0.074 & 0.03 & 0.91 \\
\hline & & $(1.10)$ & $(1.63)$ & $(1.69)$ & $(-1.00)$ & $(-0.53)$ & $(-0.54)$ & & {$[0.46]$} \\
\hline \multirow[t]{2}{*}{ Chile } & Feb 85 & $0.028^{*}$ & 0.219 & $0.143^{*}$ & 0.170 & $-0.160 *$ & 0.693 & 0.14 & 5.56 \\
\hline & & $(4.32)$ & $(1.46)$ & $(2.04)$ & $(0.42)$ & $(-3.08)$ & $(1.68)$ & & {$[0.00]$} \\
\hline \multirow[t]{2}{*}{ Colombia } & Feb 87 & $0.020^{*}$ & 0.012 & 0.161 & 1.537 & -0.114 & 0.106 & 0.00 & 1.37 \\
\hline & & $(2.04)$ & $(0.07)$ & $(1.28)$ & $(1.65)$ & $(-0.93)$ & $(0.29)$ & & {$[0.25]$} \\
\hline \multirow[t]{2}{*}{ Greece } & Feb 85 & 0.017 & 0.439 & 0.034 & -0.654 & 0.073 & 0.189 & 0.01 & 0.36 \\
\hline & & (1.68) & $(1.86)$ & $(0.26)$ & $(-0.96)$ & $(0.64)$ & $(0.58)$ & & {$[0.84]$} \\
\hline \multirow[t]{2}{*}{ India } & Feb 85 & 0.012 & -0.141 & -0.055 & 0.472 & 0.043 & $-0.644 *$ & 0.00 & 1.29 \\
\hline & & $(0.96)$ & $(-0.71)$ & $(-0.19)$ & $(0.46)$ & $(0.41)$ & $(-2.26)$ & & {$[0.28]$} \\
\hline \multirow[t]{2}{*}{ Indonesia } & Jan 90 & -0.006 & $0.556^{*}$ & $0.452^{*}$ & 0.596 & N/A & $-1.820 *$ & 0.37 & 16.68 \\
\hline & & $(-0.43)$ & $(2.33)$ & $(2.13)$ & $(0.42)$ & & $(-6.85)$ & & {$[0.00]$} \\
\hline \multirow[t]{2}{*}{ Jordan } & Feb 85 & 0.005 & 0.166 & $-0.373^{*}$ & 0.469 & -0.012 & $-0.457 *$ & 0.08 & 3.59 \\
\hline & & $(1.28)$ & $(1.74)$ & $(1.96)$ & $(1.71)$ & $(-0.32)$ & $(-2.55)$ & & {$[0.01]$} \\
\hline \multirow[t]{2}{*}{ Korea } & Feb 85 & -0.005 & $0.757 *$ & -0.006 & 0.118 & $0.254^{*}$ & $-1.143 *$ & 0.35 & 16.48 \\
\hline & & $(-0.56)$ & $(4.59)$ & $(-0.07)$ & $(0.09)$ & $(2.40)$ & $(-7.36)$ & & {$[0.00]$} \\
\hline \multirow[t]{2}{*}{ Malaysia } & $\begin{array}{l}\text { Jan } 89 \\
\end{array}$ & -0.010 & $0.840^{*}$ & 0.242 & 2.451 & -0.028 & $2.086^{*}$ & 0.38 & 5.84 \\
\hline & & $(-1.07)$ & $(4.88)$ & $(1.38)$ & $(1.18)$ & $(-0.26)$ & (4.19) & & {$[0.00]$} \\
\hline \multirow[t]{2}{*}{ Mexico } & Feb 87 & 0.007 & $0.733^{*}$ & -0.119 & $1.295^{*}$ & 0.321 & $-0.914 *$ & 0.28 & 24.71 \\
\hline & & $(0.51)$ & $(2.27)$ & $(-0.57)$ & $(2.13)$ & $(1.86)$ & $(-9.82)$ & & {$[0.00]$} \\
\hline \multirow[t]{2}{*}{ Nigeria } & Feb 85 & 0.017 & 0.045 & 0.226 & 0.106 & 0.184 & $1.177^{*}$ & 0.27 & 15.30 \\
\hline & & $(1.10)$ & $(0.15)$ & $(1.35)$ & $(0.30)$ & $(1.02)$ & $(7.58)$ & & {$[0.00]$} \\
\hline \multirow[t]{2}{*}{ Pakistan } & Feb 85 & $0.017 *$ & 0.120 & 0.266 & -0.945 & -0.048 & $-0.615 *$ & 0.01 & 2.76 \\
\hline & & $(1.86)$ & $(0.75)$ & $(1.09)$ & $(1.60)$ & $(-0.83)$ & $(-2.31)$ & & {$[0.03]$} \\
\hline \multirow[t]{2}{*}{ Philippines } & Jan 87 & -0.009 & $0.799 *$ & 0.206 & 1.384 & 0.192 & $1.801 *$ & 0.20 & 5.27 \\
\hline & & $(-0.66)$ & $(3.91)$ & $(1.16)$ & $(1.13)$ & $(1.44)$ & $(4.21)$ & & {$[0.00]$} \\
\hline \multirow[t]{2}{*}{ Portugal } & Feb 90 & -0.003 & $0.855^{*}$ & 0.085 & 0.472 & -0.236 & 0.122 & 0.34 & 0.57 \\
\hline & & $(-0.36)$ & $(6.91)$ & $(0.68)$ & $(0.44)$ & $(-1.26)$ & $(0.64)$ & & {$[0.69]$} \\
\hline \multirow[t]{2}{*}{ Taiwan } & Feb 92 & -0.009 & $0.944 *$ & 1.239 & -1.153 & 0.118 & $-1.439 *$ & 0.13 & 2.20 \\
\hline & & $(-0.39)$ & $(2.51)$ & $(0.70)$ & $(-0.64)$ & $(1.15)$ & $(-2.49)$ & & {$[0.08]$} \\
\hline \multirow[t]{2}{*}{ Thailand } & Jan 89 & -0.016 & $1.013^{*}$ & 0.078 & $1.708^{*}$ & 0.292 & -0.678 & 0.17 & 1.96 \\
\hline & & $(-1.58)$ & $(3.42)$ & $(0.41)$ & $(1.87)$ & $(1.88)$ & $(-1.10)$ & & {$[0.11]$} \\
\hline \multirow[t]{2}{*}{ Turkey } & April 87 & $0.085^{*}$ & 0.169 & -0.130 & -0.118 & -0.230 & $-1.159 *$ & 0.11 & 4.82 \\
\hline & & $(2.66)$ & $(0.41)$ & $(-0.81)$ & $(-0.17)$ & $(-1.28)$ & $(-3.33)$ & & {$[0.00]$} \\
\hline \multirow[t]{2}{*}{ Venezuela } & Feb 88 & 0.035 & -0.087 & 0.123 & -1.029 & N/A & -0.380 & -0.01 & 0.91 \\
\hline & & $(1.43)$ & $(-0.26)$ & $(0.74)$ & $(-1.47)$ & & $(-1.47)$ & & {$[0.43]$} \\
\hline \multirow[t]{2}{*}{ Zimbabwe } & Jan 91 & 0.015 & 0.480 & 0.087 & -1.120 & -0.050 & $-0.483^{*}$ & 0.03 & 2.53 \\
\hline & & $(0.83)$ & $(1.34)$ & $(0.43)$ & $(-1.62)$ & $(-0.38)$ & $(-2.11)$ & & {$[0.05]$} \\
\hline
\end{tabular}

\section{Notes:}
(a) Standard errors are adjusted for heteroskedasticity and/or autocorrelation.
(b) T-statistics appear in parentheses and are a test of the null that the coefficient is equal to zero.
(c) N/A indicates that data were not available.
(d) * indicates significance at the 5 percent level 
Table 2

Lagged Model Estimated on Monthly Returns by Country

February 1985 to December 1997

$\mathrm{R}_{\mathrm{it}}=\alpha_{\mathrm{i}}+\beta_{\mathrm{i}} \mathrm{R}_{\mathrm{wt}}+\delta_{\mathrm{i}} \mathrm{MS}_{\mathrm{it}-1}+\phi_{\mathrm{i}} \mathrm{GP}_{\mathrm{it}-1}+\gamma_{\mathrm{i}} \mathrm{RA}_{\mathrm{it}-2}+\lambda_{\mathrm{i}} \mathrm{ER}_{\mathrm{it}}+\varepsilon_{\mathrm{it}} \ldots(5)$

\begin{tabular}{|c|c|c|c|c|c|c|c|c|c|}
\hline Country & $\begin{array}{c}\text { Sample } \\
\text { Start }\end{array}$ & $\alpha_{i}$ & $\overline{\beta_{i}}$ & $\delta$ & $\phi$ & $\overline{\gamma_{i}}$ & $\overline{\lambda_{i}}$ & $\mathrm{R}^{2}$ & F-Test \\
\hline \multirow[t]{2}{*}{ Argentina } & Feb 85 & 0.020 & -0.100 & 0.131 & 0.047 & 0.036 & -0.065 & 0.00 & 1.49 \\
\hline & & $(0.86)$ & $(-0.15)$ & $(0.48)$ & $(0.41)$ & $(0.23)$ & $(-1.37)$ & & {$[0.21]$} \\
\hline \multirow[t]{2}{*}{ Brazil } & Feb 85 & 0.000 & $0.822 *$ & $0.255^{*}$ & -0.052 & -0.033 & -0.137 & 0.03 & 1.24 \\
\hline & & $(0.01)$ & $(2.14)$ & $(2.11)$ & $(-0.40)$ & $(-0.18)$ & $(-1.12)$ & & {$[0.30]$} \\
\hline \multirow[t]{2}{*}{ Chile } & Feb 85 & $0.023^{*}$ & 0.204 & $0.164^{*}$ & 0.473 & 0.085 & $1.128^{*}$ & 0.14 & 3.45 \\
\hline & & $(2.52)$ & $(1.37)$ & $(2.35)$ & $(0.86)$ & $(1.52)$ & $(2.97)$ & & {$[0.01]$} \\
\hline \multirow[t]{2}{*}{ Colombia } & Feb 87 & 0.030 & 0.080 & 0.237 & -0.666 & -0.069 & 0.008 & -0.01 & 0.77 \\
\hline & & $(1.47)$ & $(0.47)$ & $(1.54)$ & $(-0.76)$ & $(-0.77)$ & $(0.02)$ & & {$[0.54]$} \\
\hline \multirow[t]{2}{*}{ Greece } & Feb 85 & $0.022^{*}$ & $0.480 *$ & 0.143 & -1.131 & 0.207 & 0.241 & 0.03 & 1.23 \\
\hline & & $(2.02)$ & $(1.98)$ & $(0.95)$ & $(-1.22)$ & $(1.45)$ & $(0.75)$ & & {$[0.30]$} \\
\hline \multirow[t]{2}{*}{ India } & Feb 85 & 0.000 & -0.189 & 0.335 & 1.215 & 0.035 & $-0.567 *$ & 0.01 & 1.54 \\
\hline & & $(0.04)$ & $(-0.94)$ & $(1.13)$ & $(1.18)$ & $(0.33)$ & $(-1.99)$ & & {$[0.19]$} \\
\hline \multirow[t]{2}{*}{ Indonesia } & Jan 90 & 0.014 & $0.676^{*}$ & $-0.434 *$ & -1.09 & N/A & $-1.716^{*}$ & 0.38 & 16.60 \\
\hline & & $(1.00)$ & $(2.84)$ & $(-2.01)$ & $(-0.78)$ & & $(-6.68)$ & & {$[0.00]$} \\
\hline \multirow[t]{2}{*}{ Jordan } & Feb 85 & 0.006 & 0.171 & 0.036 & 0.034 & -0.052 & $-0.397^{*}$ & 0.03 & 1.78 \\
\hline & & $(1.31)$ & $(1.76)$ & $(0.19)$ & $(0.12)$ & $(-1.30)$ & $(-2.09)$ & & {$[0.13]$} \\
\hline \multirow[t]{2}{*}{ Korea } & Feb 85 & 0.005 & $0.680 *$ & 0.018 & -1.136 & -0.044 & $-1.163^{*}$ & 0.32 & 14.56 \\
\hline & & $(0.49)$ & $(4.11)$ & $(0.19)$ & $(-0.83)$ & $(-0.40)$ & $(-7.57)$ & & {$[0.00]$} \\
\hline \multirow[t]{2}{*}{ Malaysia } & Jan 89 & -0.010 & $0.708^{*}$ & $0.357^{*}$ & 1.754 & 0.088 & $1.922 *$ & 0.36 & 5.00 \\
\hline & & $(-1.37)$ & (4.64) & $(2.21)$ & $(0.96)$ & (1.14) & $(4.12)$ & & {$[0.00]$} \\
\hline \multirow[t]{2}{*}{ Mexico } & Feb 87 & 0.002 & $0.717 *$ & 0.075 & $1.243^{*}$ & -0.013 & $-0.855^{*}$ & 0.28 & 32.81 \\
\hline & & $(0.15)$ & $(2.51)$ & $(0.66)$ & $(2.06)$ & $(-0.10)$ & $(-10.51)$ & & {$[0.00]$} \\
\hline \multirow[t]{2}{*}{ Nigeria } & Feb 85 & $0.024^{*}$ & 0.068 & -0.114 & 0.061 & -0.318 & $1.189 *$ & 0.26 & 60.22 \\
\hline & & $(2.88)$ & $(0.24)$ & $(-0.79)$ & $(0.21)$ & $(-1.07)$ & $(13.28)$ & & {$[0.00]$} \\
\hline \multirow[t]{2}{*}{ Pakistan } & Feb 85 & 0.004 & 0.124 & $0.657^{*}$ & 0.074 & -0.003 & $-0.504^{*}$ & 0.02 & 2.98 \\
\hline & & $(0.47)$ & $(0.87)$ & $(2.45)$ & $(0.15)$ & $(-0.05)$ & $(-2.10)$ & & {$[0.02]$} \\
\hline \multirow[t]{2}{*}{ Philippines } & Jan 87 & 0.002 & $0.835^{*}$ & -0.027 & 0.972 & -0.155 & $1.775^{*}$ & 0.19 & 4.71 \\
\hline & & $(0.16)$ & $(3.67)$ & $(-0.15)$ & $(0.88)$ & $(-1.10)$ & (3.64) & & {$[0.00]$} \\
\hline \multirow[t]{2}{*}{ Portugal } & Feb 90 & 0.001 & $0.867 *$ & 0.052 & -0.348 & $0.369 *$ & 0.116 & 0.36 & 1.16 \\
\hline & & $(0.09)$ & $(6.87)$ & $(0.41)$ & $(-0.29)$ & $(2.03)$ & $(0.62)$ & & {$[0.33]$} \\
\hline \multirow[t]{2}{*}{ Taiwan } & Feb 92 & -0.004 & $1.033^{*}$ & -0.271 & 1.012 & -0.164 & -0.211 & 0.07 & 1.46 \\
\hline & & $(-0.24)$ & $(2.75)$ & $(-0.21)$ & $(0.91)$ & $(-1.39)$ & $(-1.15)$ & & {$[0.23]$} \\
\hline \multirow[t]{2}{*}{ Thailand } & Jan 89 & -0.007 & $0.906^{*}$ & 0.032 & -0.457 & 0.128 & -0.705 & 0.12 & 0.58 \\
\hline & & $(-0.56)$ & $(3.06)$ & $(0.19)$ & $(-0.28)$ & $(0.78)$ & $(-1.16)$ & & {$[0.68]$} \\
\hline \multirow[t]{2}{*}{ Turkey } & April 87 & 0.065 & 0.204 & $0.368 *$ & -0.312 & -0.211 & $-1.092 *$ & 0.14 & 6.22 \\
\hline & & $(1.91)$ & $(0.51)$ & $(2.27)$ & $(-0.58)$ & $(-1.15)$ & $(-3.93)$ & & {$[0.00]$} \\
\hline \multirow[t]{2}{*}{ Venezuela } & Feb 88 & 0.027 & -0.161 & 0.141 & -0.621 & N/A & -0.141 & -0.01 & 1.09 \\
\hline & & $(1.40)$ & $(-0.54)$ & $(0.90)$ & $(-1.37)$ & & $(-0.90)$ & & {$[0.36]$} \\
\hline \multirow[t]{2}{*}{ Zimbabwe } & Jan 91 & -0.006 & 0.548 & -0.060 & 0.198 & 0.132 & $-0.503 *$ & 0.01 & 3.06 \\
\hline & & $(-0.26)$ & $(1.66)$ & $(-0.41)$ & $(0.29)$ & $(1.46)$ & $(-2.25)$ & & {$[0.03]$} \\
\hline
\end{tabular}

Notes:

(a) Standard errors are adjusted for heteroskedasticity and/or autocorrelation.

(b) T-statistics appear in parentheses and are a test of the null that the coefficient is equal to zero.

(c) N/A indicates data were unavailable.

(d) * indicates significance at the 5 percent level. 


\section{Table 3}

Full Model Estimated on Monthly Returns by Country February 1991 to December 1997

$R_{i t}=\alpha_{i}+\beta_{i} R_{w t}+\delta_{i} M_{i t}+\phi G_{i t}+\gamma_{i} R A_{i t}+\lambda_{i} E_{i t}+\chi_{i} C R_{i t}+\eta_{i} T_{i t}+\varphi_{1} I R_{i t}+\kappa_{i} R_{i t}+\mu_{i} P_{i t}+\nu_{i} D Y_{i t}+\varepsilon_{i t} \quad(6)$

\begin{tabular}{|c|c|c|c|c|c|c|c|c|c|c|c|c|c|}
\hline & $\alpha_{i}$ & $\beta_{\mathrm{i}}$ & $\delta_{1}$ & $\phi$ & $\gamma_{\mathrm{i}}$ & $\lambda_{\mathrm{i}}$ & $\chi_{\mathrm{I}}$ & $\eta_{\mathrm{i}}$ & $\varphi_{\mathrm{I}}$ & $\kappa_{\mathrm{i}}$ & $\mu_{\mathrm{i}}$ & $v_{\mathrm{i}}$ & $\mathrm{R}^{2}$ \\
\hline \multirow[t]{2}{*}{$\mathrm{AG}$} & -0.006 & 0.695 & 0.103 & 0.627 & 0.265 & N/A & -0.077 & -0.186 & -0.090 & $0.530^{*}$ & 0.057 & 0.024 & 0.30 \\
\hline & $(-0.47)$ & $(1.61)$ & $(0.43)$ & $(0.94)$ & $(1.19)$ & & $(-0.10)$ & $(-0.89)$ & $(-1.07)$ & $(2.30)$ & $(1.85)$ & $(0.25)$ & \\
\hline \multirow[t]{2}{*}{ BR } & -0.000 & $0.955^{*}$ & 0.095 & $0.281 *$ & 0.130 & $-0.333^{*}$ & 1.371 & $-0.265^{*}$ & -0.102 & $0.644 *$ & 0.005 & $-0.078^{*}$ & 0.43 \\
\hline & $(-0.01)$ & $(2.56)$ & $(1.38)$ & $(2.05)$ & $(0.73)$ & $(-2.93)$ & $(1.75)$ & $(-2.51)$ & $(-1.60)$ & $(3.13)$ & $(1.82)$ & $(-2.67)$ & \\
\hline \multirow[t]{2}{*}{$\mathrm{CL}$} & $0.011^{*}$ & 0.261 & 0.019 & $-1.162^{*}$ & -0.134 & $1.817^{*}$ & 0.445 & 0.095 & -0.028 & 0.053 & $0.547^{*}$ & $-0.201 *$ & 0.78 \\
\hline & $(2.29)$ & $(1.88)$ & $(0.31)$ & $(-2.11)$ & $(-1.67)$ & $(6.83)$ & $(0.89)$ & $(1.55)$ & $(-1.25)$ & $(0.86)$ & $(8.89)$ & $(-3.79)$ & \\
\hline $\mathrm{CB}$ & $\begin{array}{c}0.016^{*} \\
(3.74)\end{array}$ & $\begin{array}{l}0.022 \\
(0.19)\end{array}$ & $\begin{array}{c}0.230^{*} \\
(4.12)\end{array}$ & $\begin{array}{l}-0.116 \\
(-0.22)\end{array}$ & $\begin{array}{l}0.037 \\
(0.58)\end{array}$ & $\begin{array}{l}0.301^{*} \\
(2.08)\end{array}$ & $\begin{array}{l}0.127 \\
(0.75)\end{array}$ & N/A & $\begin{array}{l}-0.089 \\
(-1.19)\end{array}$ & $\begin{array}{l}-0.046 \\
(-0.75)\end{array}$ & $\begin{array}{c}0.246^{*} \\
(5.33)\end{array}$ & $\begin{array}{c}-0.398^{*} \\
(-4.67)\end{array}$ & 0.78 \\
\hline \multirow[t]{2}{*}{ GR } & -0.005 & $0.481^{*}$ & 0.021 & -0.468 & 0.059 & $0.761^{*}$ & 0.772 & N/A & $-0.384^{*}$ & $0.331^{*}$ & $0.075^{*}$ & -0.002 & 0.70 \\
\hline & $(-0.79)$ & $(3.49)$ & $(0.29)$ & $(-1.18)$ & $(1.17)$ & $(3.28)$ & $(1.56)$ & & $(-2.14)$ & $(2.37)$ & $(2.56)$ & $(-0.72)$ & \\
\hline \multirow[t]{2}{*}{ IN } & 0.000 & 0.057 & 0.164 & 0.540 & $0.118^{*}$ & $-0.705^{*}$ & 0.111 & -0.070 & -0.002 & $0.119^{*}$ & $0.745^{*}$ & $-0.075^{*}$ & 0.91 \\
\hline & $(0.02)$ & $\begin{array}{l}(0.50) \\
\end{array}$ & $(1.15)$ & $(1.15)$ & $(2.00)$ & $(-5.91)$ & $\begin{array}{l}(0.79) \\
\end{array}$ & $(-1.56)$ & $\begin{array}{l}(-0.31) \\
\end{array}$ & $\begin{array}{l}(2.25) \\
\end{array}$ & $\begin{array}{l}(21.13) \\
\end{array}$ & $(-2.30)$ & \\
\hline \multirow[t]{2}{*}{ ID } & 0.009 & 0.264 & 0.146 & -1.250 & N/A & $-1.196^{*}$ & -0.145 & -0.055 & -0.008 & $0.309^{*}$ & $0.556^{*}$ & -0.015 & 0.80 \\
\hline & $(1.43)$ & $(1.72)$ & $(1.22)$ & $(-1.28)$ & & $(-4.62)$ & $(-0.25)$ & $(-0.63)$ & $(-0.74)$ & $(2.08)$ & $(4.34)$ & $(-1.23)$ & \\
\hline \multirow[t]{2}{*}{$\mathrm{JO}$} & 0.006 & 0.222 & -0.218 & 0.129 & -0.027 & N/A & 0.016 & -0.007 & N/A & 0.010 & $0.197^{*}$ & N/A & 0.14 \\
\hline & $(1.15)$ & (1.74) & $(-0.97)$ & $(0.34)$ & $\begin{array}{l}(-0.59) \\
\end{array}$ & & $(0.13)$ & $(-0.35)$ & & $\begin{array}{l}(0.26) \\
\end{array}$ & $(3.56)$ & & \\
\hline \multirow[t]{2}{*}{$\mathrm{KO}$} & -0.014 & 0.212 & -0.071 & 1.258 & 0.292 & $-0.852^{*}$ & -0.094 & -0.164 & -0.147 & $0.331^{*}$ & $0.075^{*}$ & -0.002 & 0.49 \\
\hline & $(-1.18)$ & $\begin{array}{l}(0.77) \\
\end{array}$ & $(-0.52)$ & $(0.64)$ & $(1.26)$ & $(-4.61)$ & $(-0.14)$ & $(-1.09)$ & $(-1.54)$ & $(2.37)$ & $(2.56)$ & $(-0.72)$ & \\
\hline \multirow[t]{2}{*}{ MY } & 0.005 & -0.107 & -0.083 & 1.466 & -0.111 & $1.259 *$ & -0.329 & $0.090 *$ & $0.082 *$ & 0.096 & $0.732 *$ & $-0.113 *$ & 0.92 \\
\hline & $\begin{array}{l}(1.33) \\
\end{array}$ & $(-1.06)$ & $(-1.16)$ & $(1.60)$ & $(-1.55)$ & $(5.62)$ & $(-1.41)$ & $(2.58)$ & $(2.03)$ & $(1.48)$ & $(9.62)$ & $(-3.36)$ & \\
\hline \multirow[t]{2}{*}{ MX } & 0.016 & 0.321 & 0.002 & -0.404 & 0.449 & $-0.712^{*}$ & $1.259^{*}$ & 0.027 & $-0.115^{*}$ & $0.346^{*}$ & $0.070^{*}$ & $-0.133^{*}$ & 0.65 \\
\hline & $(1.40)$ & $(1.25)$ & $(0.02)$ & $(-0.76)$ & $(1.59)$ & $(-10.18)$ & $(2.63)$ & $(0.20)$ & $(-2.64)$ & $(2.42)$ & $(4.56)$ & $(-2.92)$ & \\
\hline \multirow[t]{2}{*}{$\mathrm{NG}$} & -0.004 & 0.088 & 0.407 & 0.061 & -0.138 & N/A & 0.600 & N/A & N/A & 0.521 & 0.051 & -0.311 & -0.01 \\
\hline & $(-0.14)$ & $(0.11)$ & $(0.66)$ & $(0.14)$ & $(-0.64)$ & & $(0.82)$ & & & $(1.39)$ & $(0.33)$ & $(-1.16)$ & \\
\hline \multirow[t]{2}{*}{ PK } & -0.001 & 0.194 & $0.218^{*}$ & 0.393 & -0.03 & $-0.682^{*}$ & 0.382 & 0.029 & 0.001 & 0.077 & $0.486^{*}$ & $-0.270^{*}$ & 0.73 \\
\hline & $(-0.08)$ & $(1.08)$ & $(2.00)$ & $(0.63)$ & $(-0.64)$ & $(-3.79)$ & $(1.42)$ & $(0.74)$ & $(0.17)$ & $(1.17)$ & $(5.21)$ & $(-3.85)$ & \\
\hline \multirow[t]{2}{*}{$\mathrm{PH}$} & 0.005 & 0.165 & 0.046 & 0.161 & -0.050 & $1.352 *$ & -0.153 & $0.116^{*}$ & 0.082 & $0.263^{*}$ & $0.535^{*}$ & -0.038 & 0.75 \\
\hline & $(0.67)$ & $(1.15)$ & $(0.37)$ & $(0.18)$ & $(-0.51)$ & $(5.81)$ & $(-0.95)$ & $(2.19)$ & $(1.52)$ & $(2.28)$ & $(3.79)$ & $(-1.14)$ & \\
\hline \multirow[t]{2}{*}{$\mathrm{PT}$} & -0.003 & $0.593^{*}$ & 0.033 & 1.387 & $-0.395^{*}$ & $0.332^{*}$ & -0.462 & -0.005 & 0.039 & $0.119^{*}$ & $0.216^{*}$ & $-0.084 *$ & 0.52 \\
\hline & $(-0.44)$ & $\begin{array}{l}(4.13) \\
\end{array}$ & $\begin{array}{l}(0.30) \\
\end{array}$ & $(1.10)$ & $(-2.43)$ & $(2.00)$ & $(-1.20)$ & $(-0.20)$ & $(1.03)$ & $(2.92)$ & $(2.63)$ & $(-2.44)$ & \\
\hline \multirow[t]{2}{*}{ TW } & -0.005 & 0.017 & 0.456 & 0.105 & -0.026 & N/A & 0.531 & 0.020 & 0.030 & $0.161^{*}$ & $0.673^{*}$ & -0.003 & 0.83 \\
\hline & $(-0.82)$ & $(0.18)$ & $(1.52)$ & $(0.24)$ & $(-0.46)$ & & $(1.04)$ & $(0.43)$ & $(0.68)$ & $(2.65)$ & $(12.81)$ & $(-1.49)$ & \\
\hline \multirow[t]{2}{*}{$\mathrm{TH}$} & 0.003 & -0.120 & 0.049 & -1.242 & -0.094 & -0.054 & 0.000 & 0.118 & -0.032 & $0.870^{*}$ & $0.035^{*}$ & $-0.347^{*}$ & 0.70 \\
\hline & $(0.31)$ & $(-0.54)$ & $(0.47)$ & $(-1.26)$ & $(-0.67)$ & $(-0.33)$ & $(0.00)$ & (1.54) & $(-1.47)$ & $(6.51)$ & $(2.92)$ & $(4.04)$ & \\
\hline \multirow[t]{2}{*}{ TK } & -0.006 & -0.025 & -0.101 & $1.126^{*}$ & 0.055 & $-1.167 *$ & 0.377 & 0.120 & $0.198^{*}$ & $0.457 *$ & $0.549 *$ & -0.083 & 0.72 \\
\hline & $(-0.33)$ & $(-0.08)$ & $(-0.90)$ & $(2.85)$ & $(0.39)$ & $(-6.55)$ & $(1.46)$ & $(0.95)$ & $(2.80)$ & $(2.18)$ & $(6.78)$ & $(-1.89)$ & \\
\hline \multirow[t]{2}{*}{ VE } & -0.015 & 0.133 & 0.025 & 0.150 & N/A & -0.235 & 0.511 & 0.120 & -0.045 & 0.237 & 0.069 & $-0.241 *$ & 0.12 \\
\hline & $(-0.40)$ & $\begin{array}{l}(0.37) \\
\end{array}$ & $(0.19)$ & $(0.12)$ & & $(-0.67)$ & $\begin{array}{l}(1.08) \\
\end{array}$ & $(1.73)$ & $(-0.46)$ & $(1.25)$ & $(1.79)$ & $(-2.32)$ & \\
\hline \multirow[t]{2}{*}{$\mathrm{ZI}$} & 0.002 & 0.055 & 0.049 & -0.135 & 0.007 & $-0.783^{*}$ & 0.245 & N/A & -0.153 & -0.078 & $0.754 *$ & N/A & 0.64 \\
\hline & $\begin{array}{l}(0.19) \\
\end{array}$ & $\begin{array}{l}(0.29) \\
\end{array}$ & $\begin{array}{l}(0.42) \\
\end{array}$ & $(-0.45)$ & $\begin{array}{l}(0.12) \\
\end{array}$ & $\begin{array}{c}(-5.99) \\
\end{array}$ & $\begin{array}{l}(0.43) \\
\end{array}$ & & $(-1.55)$ & $(-1.09)$ & $(6.66)$ & & \\
\hline
\end{tabular}

Notes:

AG - Argentina, BR-Brazil, CL - Chile, CB - Colombia, GR - Greece, IN - India, ID - Indonesia, JO -

Jordan, KO - South Korea, MY - Malaysia, MX - Mexico, NG - Nigeria, PK - Pakistan, PH -

Philippines, PT - Portugal, TW - Taiwan, TH - Thailand, TK - Turkey, VE - Venezuela and ZI -

Zimbabwe.

* indicates significance at the 5 percent level. 
Table 4

Principal Component Loadings from the Variable Set

February 1991 to December 1997

\begin{tabular}{|l|c|c|c|c|}
\hline & PC1 & PC2 & PC3 & PC4 \\
\hline MS & -0.10 & 0.36 & -0.05 & 0.06 \\
\hline GP & -0.03 & -0.09 & 0.03 & 0.06 \\
\hline RA & 0.43 & 0.00 & -0.04 & -0.05 \\
\hline ER & 0.03 & -0.01 & 0.00 & -0.04 \\
\hline WI & -0.13 & 0.01 & -0.09 & 0.37 \\
\hline CR & -0.02 & -0.01 & 0.24 & 0.04 \\
\hline IR & -0.01 & 0.05 & -0.07 & -0.11 \\
\hline TS & 0.52 & 0.24 & 0.03 & -0.14 \\
\hline PE & -0.01 & 0.02 & 0.05 & 0.30 \\
\hline DY & 0.08 & 0.02 & 0.09 & -0.30 \\
\hline LAREG & -0.01 & 0.08 & 0.01 & 0.60 \\
\hline ASREG & -0.02 & 0.12 & 0.41 & 0.73 \\
\hline EUREG & -0.12 & -0.06 & -0.32 & 0.39 \\
\hline OTHREG & -0.46 & -0.10 & 0.26 & 0.13 \\
\hline
\end{tabular}

Notes:

(a) MS = Money Supply, GP = Goods Price, RA = Real Activity. ER = Exchange Rate, WI = World Market Return, CR = Country Risk, IR = Interest Rate, TS = Trade Sector, PE = Price-Earnings ratio, DY = Dividend Yield, LAREG, ASREG,EUREG and OTHREG are equally weighted regional indices for Latin America, Asia, Europe and a combined Middle East / Africa region respectively.

(b) the loadings are calculated by taking the average of the correlations between the variables and principal components. 
Table 5

Regression of Returns on Principal Components by Country

February 1991 to December 1997

$\mathrm{R}_{\mathrm{it}}=\alpha_{\mathrm{i}}+\beta_{1 \mathrm{i}} \mathrm{PC}_{1 \mathrm{t}}+\beta_{2 \mathrm{i}} \mathrm{PC}_{2 \mathrm{t}}+\beta_{3 \mathrm{i}} \mathrm{PC}_{3 \mathrm{t}}+\beta_{4 \mathrm{i}} \mathrm{PC}_{4 \mathrm{t}}+\varepsilon_{\mathrm{it}}$

\begin{tabular}{|c|c|c|c|c|c|c|}
\hline & $\alpha_{i}$ & $\beta_{1 \mathrm{i}}$ & $\beta_{2 \mathrm{i}}$ & $\beta_{3 \mathrm{i}}$ & $\beta_{4 \mathrm{i}}$ & $\mathrm{R}^{2}$ \\
\hline \multicolumn{7}{|c|}{ Latin America } \\
\hline \multirow[t]{2}{*}{$\mathrm{AG}$} & 0.025 & 0.003 & $0.097 *$ & 0.062 & $0.116^{*}$ & 0.11 \\
\hline & $(1.86)$ & $(0.11)$ & $(4.07)$ & $(2.38)$ & $(3.31)$ & \\
\hline \multirow[t]{2}{*}{$\mathrm{BR}$} & $0.026^{*}$ & $-0.079 *$ & 0.066 & 0.047 & $0.155^{*}$ & 0.20 \\
\hline & $(2.06)$ & $(-3.21)$ & $(1.52)$ & $(1.29)$ & $(4.42)$ & \\
\hline \multirow[t]{2}{*}{$\mathrm{CL}$} & $0.015^{*}$ & $-0.060 *$ & 0.019 & $0.056^{*}$ & $0.077 *$ & 0.28 \\
\hline & $(2.38)$ & $(-3.73)$ & $(1.16)$ & $(4.48)$ & $(3.30)$ & \\
\hline \multirow[t]{2}{*}{$\mathrm{CB}$} & $0.024 *$ & -0.053 & $0.067 *$ & $0.065^{*}$ & 0.030 & 0.14 \\
\hline & $(2.64)$ & $(-1.92)$ & $(2.22)$ & $(2.77)$ & $(0.85)$ & \\
\hline \multirow[t]{2}{*}{ MX } & 0.013 & -0.011 & 0.052 & 0.045 & $0.105^{*}$ & 0.09 \\
\hline & $(1.21)$ & $(-0.43)$ & $(1.45)$ & $(1.25)$ & $(2.59)$ & \\
\hline \multirow[t]{2}{*}{$\mathrm{VE}$} & 0.000 & -0.027 & 0.045 & 0.037 & -0.001 & 0.02 \\
\hline & $(0.02)$ & $(-0.83)$ & $(1.96)$ & $(1.21)$ & $(-0.02)$ & \\
\hline \multicolumn{7}{|l|}{ Asia } \\
\hline \multirow[t]{2}{*}{ IN } & 0.004 & $-0.058 *$ & 0.039 & $0.068^{*}$ & $0.113 *$ & 0.22 \\
\hline & $(0.43)$ & $(-2.13)$ & $(1.48)$ & $(2.98)$ & $(2.79)$ & \\
\hline \multirow[t]{2}{*}{ ID } & -0.011 & $-0.073 *$ & 0.000 & $0.181^{*}$ & $0.136^{*}$ & 0.45 \\
\hline & $(-1.25)$ & $(-4.41)$ & $(0.00)$ & $(3.70)$ & $(3.55)$ & \\
\hline \multirow[t]{2}{*}{$\mathrm{KO}$} & -0.017 & -0.032 & $-0.060 *$ & $0.151^{*}$ & $0.080 *$ & 0.34 \\
\hline & $(-1.98)$ & $(-1.81)$ & $(-2.59)$ & $(4.31)$ & $(2.64)$ & \\
\hline \multirow[t]{2}{*}{ MY } & -0.002 & -0.028 & 0.041 & $0.158^{*}$ & 0.049 & 0.39 \\
\hline & $(-0.28)$ & $(-1.27)$ & $(1.69)$ & $(4.91)$ & $(1.41)$ & \\
\hline \multirow[t]{2}{*}{$\mathrm{PK}$} & 0.010 & -0.034 & $0.093^{*}$ & $0.073^{*}$ & 0.043 & 0.17 \\
\hline & $(1.04)$ & $(-1.66)$ & $(3.43)$ & $(3.13)$ & $(1.28)$ & \\
\hline \multirow[t]{2}{*}{$\mathrm{PH}$} & 0.006 & $-0.037 *$ & $0.060 *$ & $0.156^{*}$ & $0.060^{*}$ & 0.41 \\
\hline & $(0.80)$ & $(-1.98)$ & $(2.39)$ & $(6.91)$ & $(1.99)$ & \\
\hline \multirow[t]{2}{*}{ TW } & 0.007 & $-0.047 *$ & $0.080 *$ & $0.109^{*}$ & 0.030 & 0.22 \\
\hline & $(0.71)$ & $(-2.32)$ & $(2.17)$ & $(3.37)$ & $(0.96)$ & \\
\hline \multirow[t]{2}{*}{$\mathrm{TH}$} & -0.012 & $-0.045 *$ & $0.063 *$ & $0.178^{*}$ & $0.125^{*}$ & 0.43 \\
\hline & $(-1.41)$ & $(-2.23)$ & $(2.67)$ & $(4.68)$ & $(3.61)$ & \\
\hline \multicolumn{7}{|c|}{ Europe } \\
\hline \multirow[t]{2}{*}{ GR } & 0.002 & $-0.079 *$ & $0.035^{*}$ & -0.013 & $0.090 *$ & 0.29 \\
\hline & $(0.29)$ & $(-4.36)$ & $(2.19)$ & $(-0.60)$ & $(4.01)$ & \\
\hline \multirow[t]{2}{*}{ PT } & 0.011 & -0.027 & $0.032 *$ & -0.016 & $0.058^{*}$ & 0.15 \\
\hline & $(1.95)$ & $(-1.78)$ & $(2.15)$ & $(-1.20)$ & $(2.96)$ & \\
\hline \multirow[t]{2}{*}{ TK } & 0.004 & -0.054 & $0.113^{*}$ & -0.081 & 0.077 & 0.08 \\
\hline & $(0.27)$ & $(-1.27)$ & $(3.41)$ & $(-2.47)$ & $(1.19)$ & \\
\hline \multicolumn{7}{|c|}{ Other (Africa and Middle East) } \\
\hline \multirow[t]{2}{*}{$\mathrm{JO}$} & 0.009 & -0.015 & 0.021 & 0.007 & 0.014 & 0.03 \\
\hline & $(2.25)$ & $(-2.01)$ & $(2.01)$ & $(0.51)$ & $(0.98)$ & \\
\hline \multirow[t]{2}{*}{$\mathrm{NG}$} & 0.014 & $-0.171 *$ & -0.010 & 0.026 & -0.124 & 0.15 \\
\hline & $(0.73)$ & $(-1.99)$ & $(-0.23)$ & $(0.68)$ & $(-1.42)$ & \\
\hline $\mathrm{ZI}$ & -0.007 & -0.044 & $-0.088 *$ & $0.131^{*}$ & 0.001 & 0.20 \\
\hline & $(-0.66)$ & $(-1.52)$ & $(-2.32)$ & $(2.95)$ & $(0.01)$ & \\
\hline
\end{tabular}

Notes:

(a) * indicates significance at the 5 percent level.

(b) Standard errors adjusted for heteroskedasticity. 
Table 6 - Panel A

\section{F-Test of Identical Exposure to Principal Components by Region}

\begin{tabular}{|c|c|c|c|}
\hline PC1 & PC2 & PC3 & PC4 \\
\hline Emerging Stock Markets (20 markets) \\
\hline 2.141 & 2.486 & 4.633 & 3.048 \\
\hline$[0.00]$ & {$[0.00]$} & {$[0.00]$} & {$[0.00]$} \\
\hline \multicolumn{4}{|c|}{ Latin America (6 markets) } \\
\hline 1.371 & 0.577 & 0.072 & 2.201 \\
\hline$[0.23]$ & {$[0.72]$} & {$[0.99]$} & {$[0.05]$} \\
\hline Asia (8 markets) \\
\hline 0.566 & 3.64 & 2.78 & 1.92 \\
\hline$[0.78]$ & {$[0.00]$} & {$[0.01]$} & {$[0.06]$} \\
\hline Europe (3 markets) \\
\hline 1.044 & 1.989 & 1.243 & 0.199 \\
\hline$[0.35]$ & {$[0.14]$} & {$[0.29]$} & {$[0.82]$} \\
\hline Other (3 markets) \\
\hline 7.893 & 2.208 & 2.834 & 3.128 \\
\hline$[0.00]$ & {$[0.11]$} & {$[0.06]$} & {$[0.05]$} \\
\hline
\end{tabular}

Notes:

(a) * indicates the null hypothesis of identical coefficients is rejected at the $5 \%$ level.

(b) p-values are in square brackets

Table 6 - Panel B

F-Test of No Exposure to Principal Components by Region

\begin{tabular}{|l|c|c|c|}
\hline PC1 & PC2 & PC3 & PC4 \\
\hline Emerging Stock Markets (20 marke ts) \\
\hline 6.232 & 4.585 & 12.988 & 6.885 \\
\hline$[0.00]$ & {$[0.00]$} & {$[0.00]$} & {$[0.00]$} \\
\hline \multicolumn{4}{|c|}{ Latin America (6 markets) } \\
\hline 6.352 & 2.910 & 3.353 & 5.501 \\
{$[0.00]$} & {$[0.01]$} & {$[0.00]$} & {$[0.00]$} \\
\hline Asia (8 markets) \\
\hline 4.578 & 5.078 & 17.928 & 7.604 \\
\hline$[0.00]$ & {$[0.00]$} & {$[0.00]$} & {$[0.00]$} \\
\hline Europe (3 markets) \\
\hline 7.276 & 2.682 & 0.971 & 5.323 \\
\hline$[0.00]$ & {$[0.05]$} & {$[0.41]$} & {$[0.00]$} \\
\hline Other (3 markets) \\
\hline 6.247 & 3.322 & 4.844 & 1.603 \\
\hline$[0.00]$ & {$[0.02]$} & {$[0.00]$} & {$[0.19]$} \\
\hline \multicolumn{4}{|c|}{}
\end{tabular}

Notes:

(a) * indicates the null hypothesis of identical coefficients is rejected at the 5\% level.

(b) p-values are in square brackets 
Table 7

Pooled Regression of Returns on Principal Components by Region

February 1991 to December 1997

$\mathrm{R}_{\mathrm{it}}=\alpha_{\mathrm{i}}+\beta_{1 \mathrm{i}} \mathrm{PC}_{1 \mathrm{t}}+\beta_{2 \mathrm{i}} \mathrm{PC}_{2 \mathrm{t}}+\beta_{3 \mathrm{i}} \mathrm{PC}_{3 \mathrm{t}}+\beta_{4 \mathrm{i}} \mathrm{PC}_{4 \mathrm{t}}+\varepsilon_{\mathrm{it}}$

\begin{tabular}{|c|c|c|c|c|c|c|}
\hline & $\alpha_{i}$ & $\overline{\beta_{1 \mathrm{i}}}$ & $\overline{\beta_{2 \mathrm{i}}}$ & $\overline{\beta_{3 i}}$ & $\overline{\beta_{4 i}}$ & $\mathrm{R}^{2}$ \\
\hline \multicolumn{7}{|c|}{ Emerging Stock Markets (20 Markets) } \\
\hline & $0.006^{*}$ & $-0.049 *$ & $0.038^{*}$ & $0.072^{*}$ & $0.062^{*}$ & 0.20 \\
\hline & $(2.37)$ & $(-6.51)$ & $(4.43)$ & $(7.12)$ & $(5.81)$ & \\
\hline \multicolumn{7}{|c|}{ Latin America (6 Markets) } \\
\hline & $0.017^{*}$ & $-0.038^{*}$ & $0.058^{*}$ & $0.052^{*}$ & $0.080 *$ & 0.11 \\
\hline & $(3.61)$ & $(-3.22)$ & $(4.37)$ & $(4.29)$ & $(4.59)$ & \\
\hline \multicolumn{7}{|c|}{ Asia (8 Markets) } \\
\hline & -0.002 & $-0.044 *$ & $0.040 *$ & $0.134^{*}$ & $0.079 *$ & 0.33 \\
\hline & $(-0.64)$ & $(-5.81)$ & $(3.11)$ & $(8.78)$ & $(6.15)$ & \\
\hline \multicolumn{7}{|c|}{ Europe (3 Markets) } \\
\hline & 0.006 & $-0.053^{*}$ & $0.060 *$ & $-0.037^{*}$ & $0.075^{*}$ & 0.12 \\
\hline & $(0.89)$ & $(-3.15)$ & $(4.17)$ & $(-2.27)$ & $(3.07)$ & \\
\hline \multicolumn{7}{|c|}{ Other - (3 Markets) } \\
\hline & 0.005 & $-0.076^{*}$ & -0.026 & 0.055 & -0.037 & 0.16 \\
\hline & $(0.67)$ & $(-2.35)$ & $(-1.02)$ & $(1.82)$ & $(-0.97)$ & \\
\hline
\end{tabular}

Notes:

(a) * indicates significance at the 5 percent level.

(b) Standard errors adjusted for heteroskedasticity. 